\title{
Evaluation of Industrial Waste-Municipal Solid Waste Composts as a Source of Nutrients and a Study on its Effect on Soil Properties, Growth, Yield and Nutrient Uptake in Maize (Zea mays L.)
}

\author{
K.S. Karthika ${ }^{1}$, V.R.R. Parama ${ }^{2}$, C.A. Srinivasamurthy ${ }^{3}$, B. Hemalatha ${ }^{2}$ and I. Rashmi ${ }^{4}$ \\ ${ }^{1}$ ICAR-National Bureau of Soil Survey and Land Use Planning, Regional Centre, \\ Bangalore- 560 024, India \\ ${ }^{2}$ Department of Soil Science and Agricultural Chemistry, University of Agricultural Sciences, \\ GKVK, Bangalore -560 065, India \\ ${ }^{3}$ Central Agricultural University, Imphal, Manipur, India \\ ${ }^{4}$ ICAR-Indian Institute of Soil and Water Conservation, Research Centre, Kota, Rajasthan
}

*Corresponding author

\begin{abstract}
A B S T R A C T
The field evaluation of composts prepared out of enzyme industrial wastes and municipal solid waste was carried out in farmer's field in Bangalore, India using maize as a test crop

\begin{tabular}{|c|}
\hline Keywords \\
\hline $\begin{array}{l}\text { Industrial waste, } \\
\text { Municipal Solid } \\
\text { waste, Compost, } \\
\text { Soil properties, }\end{array}$ \\
\hline Article Info \\
\hline $\begin{array}{l}\text { Accepted: } \\
\text { 17 June } 2018 \\
\text { Available Online } \\
10 \text { July } 2018\end{array}$ \\
\hline
\end{tabular}
in a randomized complete block design with nine treatments and 3 replications. Two composts: MEES compost and PS compost and fertilizers were used to know the effects on soil properties and agronomic characteristics and nutrient uptake by maize plants. Application of MEES compost and PS compost resulted in increased soil $\mathrm{pH}$ and organic carbon content, but the increase was insignificant. The available nutrient concentration was slightly higher than the initial soil on application of organics like composts and waste materials. The application of $100 \%$ NPK +FYM @ 10 tha $^{-1}$ recorded higher growth, grain yield $\left(6341.47 \mathrm{~kg} \mathrm{ha}^{-1}\right)$ and straw yield $\left(11416.46 \mathrm{~kg} \mathrm{ha}^{-1}\right)$ of maize. The status of available nutrients in soil, nutrient contents in maize and uptake by maize was higher with the application of $100 \%$ NPK +FYM @ 10 tha $^{-1}$. The application of both MEES compost and PS compost resulted in grain yields of 5517.48 and $5249.12 \mathrm{~kg} \mathrm{ha}^{-1}$ and stalk yields of 9931.47 and $9448.41 \mathrm{~kg} \mathrm{ha}^{-1}$ respectively and the performance was on par with each other. Application of composts did not result in heavy metals $(\mathrm{Ni}, \mathrm{Cd}, \mathrm{Pb}$ and $\mathrm{Cr}$ ) accumulation in the soil as well as maize grain and stalk. The study thus revealed the suitability of enzyme industry wastes composts as organic nutrient source for use in agriculture.
\end{abstract}

\section{Introduction}

In India, large volumes of domestic and industrial wastes are being generated every day. Among them, enormous quantities of solid wastes are produced from the enzyme industries. Wastes are considered as environmental hazards unless the problem of their disposal is resolved in environmental friendly ways. Wastes are potential source of nutrients that goes unutilized. Recycling organic wastes to cropland provides an 
opportunity to return the nutrients towards soil for improving soil fertility and productivity. However, recycling can be achieved by appropriate biodegradation techniques. Composting is one of the methods, by which the organic wastes can be converted to composts, which can be used in agriculture as soil conditioner or as organic sources of plant nutrients. Composting is a widely accepted method for disposal of organic wastes (Goyal et al., 2005). This helps in diverting organic wastes to composting, which otherwise would be land filled (Eriksen et al., 1999). Compost, a soil conditioner when added to soil provides plant nutrients and brings about holistic improvement in soil thereby contributing to soil fertility and productivity increasing crop yields.

Composting of municipal solid waste has potential as an important recycling tool and it is increasingly used in agriculture as a soil conditioner as well as fertilizer (Hargreaves et al., 2008). Municipal solid waste (MSW) compost has recently gained attention due to the increased interest in organic agriculture and its positive effects on physical, chemical and biological properties of soil (IglesiasJimenez and Alvarez, 1993). Application of MSW compost improves the soil organic matter as well as it improves the physical, chemical and biological properties by supplying organic matter (Logan et al, 1997; Cala et al., 2005; Roca-Perez et al., 2009; Baldantoni et al., 2010). The use of MSW compost as an amendment in soils is also considered as an option for conserving organic matter levels in soils (Barral et al., 2009).

Intensive agricultural methods and cultivation of exhaustive crops have resulted in degradation of soil leading to deterioration in soil quality. The wastes considered in this study are by-products from enzyme industry. These enzyme industrial wastes namely Multiple effect evaporator salts (MEES) and primary sludge (PS) were allowed for composting using municipal solid waste as the $\mathrm{C}$ source and the mature composts were evaluated as source of organic fertilizer in this study. Maize was grown as the test crop. This experiment was undertaken to investigate the effect of industrial waste- municipal solid waste composts on soil properties, growth and yield of maize and nutrient content and uptake by maize.

\section{Materials and Methods}

A field experiment with maize (Zea mays L.) was conducted between June to October 2013 in a sandy loam soil. Two enzyme industrial waste-municipal solid waste composts and fertilizers were used to know the effects on soil properties and agronomic characteristics and nutrient uptake by maize plants.

\section{Experimental details}

The industrial wastes named multiple effect evaporator salts and primary sludge were obtained from an enzyme production based industry located in the Bangalore city, India. Municipal Solid waste/ urban solid waste was collected from the city area near the market centre located in Bangalore. The collected waste was segregated and the organic fraction was used for the production of compost. Enzyme industry al wastes were subjected to composting using urban solid waste or municipal solid waste as the carbon source or bulking agent for a period of 90 days following the heap method of composting, maintaining proper aeration and moisture throughout. During the time period, the physico-chemical, biological and biochemical characteristics were monitored and the maturity of composts was assessed using maturity/stability indicators like $\mathrm{C}: \mathrm{N}$ ratio, humic acid content, humic acid index and $\mathrm{E}_{4} / \mathrm{E}_{6}$ ratio. This process of composting resulted in two composts namely, MEES 
compost (multiple effect evaporator salts + municipal solid waste) and primary sludge (PS) compost (Primary sludge + municipal solid waste). These composts were used in this study to evaluate their effects on soil properties, growth, yield and nutrient uptake in maize.

The experiment was carried out in a field located in the Eastern Dry Zone (Zone 5) of Karnataka. The experimental site is geopositioned at $13^{0} 27^{\prime \prime} \mathrm{N}$ latitude and $77^{0} 14$ " E longitude near Nelamangala, Bangalore district. Nine treatments performed according to a Randomised Complete Block Design (RCBD) in three replicates were considered. The treatment details are $\mathrm{T}_{1}$ : Package of Practices (100\% NPK + FYM @ $10 \mathrm{t} \mathrm{ha}^{-1}$ ), $\mathrm{T}_{2}: 100 \% \mathrm{NPK}+\mathrm{FYM} @ 5 \mathrm{tha}^{-1}, \mathrm{~T}_{3}: 50 \% \mathrm{~N}$ through MEES compost $+50 \% \mathrm{~N}$ through urea $+\mathrm{P}$ and $\mathrm{K}, \mathrm{T}_{4}: 50 \% \mathrm{~N}$ through $\mathrm{PS}$ compost $+50 \% \mathrm{~N}$ through urea $+\mathrm{P}$ and $\mathrm{K}, \mathrm{T}_{5}$ : FYM @ $10 \mathrm{t} \mathrm{ha}^{-1}, \mathrm{~T}_{6}$ :MEES compost @ $10 \mathrm{t}$ ha $^{-1}, \mathrm{~T}_{7}: \mathrm{PS}$ compost @ $10 \mathrm{t} \mathrm{ha}^{-1}, \mathrm{~T}_{8}: 50 \% \mathrm{~N}$ through MEES + $50 \% \mathrm{~N}$ through FYM, T9: $50 \% \mathrm{~N}$ through PS $+50 \% \mathrm{~N}$ through FYM.

The application rates of MEES compost and PS compost were calculated by taking into account the $\mathrm{N}$ recommendation to maize. The nitrogen needs were met from the compost as well as the nitrogenous fertilizers applied. The farm yard manure, compost and wastes were applied one month prior to the start of field trial allowing sufficient time before sowing of seeds. The seeds of hybrid maize variety Hema were sown during the month of June and the experiment was conducted from June to October 2013. Soil and plant samples were collected at harvest of the crop and analysed for the changes in nutrients content. The final harvest was completed in October 2013 (10/08) when plants reached maturity (135 days after sowing). Plants were then subdivided into grain and stalk. These samples were utilized for analysis of nutrient content and uptake by maize crop.
Total nutrients in industrial wastes, composts and physico-chemical properties of soil

The industrial wastes; multiple effect evaporator salts and primary sludge and their composts were subjected to total digestion using di acid (consisting of nitric acid and perchloric acid), which would dissolve almost all the elements that could become environmentally available (Carbonell et al., 2009).

Soil samples were analysed for physicochemical properties following standard procedures. Soil chemical parameters were determined using standard analytical techniques (Jackson, 1973). Soil pH was recorded in a 1:2.5 soil: water suspension based on potentiometry, electrical conductivity (EC) based on conductometry. Soil organic carbon (OC) was determined following Walkley and Black wet digestion method. Available $\mathrm{N}$ was estimated using Kjeldahl Nitrogen distillation apparatus following alkaline permanganate method as outlined by Subbaiah and Asija, 1956. Bray's No.1 extractant was used for P extraction and $\mathrm{P}$ was estimated by Spectrophotometry (Bray and Kurtz, 1945). Available K was extracted using neutral normal ammonium acetate followed by estimation using Flame photometry. The extractable/ bioavailable micronutrient and heavy metal contents were analysed according to the procedure described by Lindsay and Norwell (1978) using DTPA (Diethyl Triamine Penta Acetic acid) solution (0.005 M DTPA + $0.01 \mathrm{M} \mathrm{CaCl}_{2}+0.1 \mathrm{M}$ TEA, pH 7.3) at room temperature. Standard metal solutions were obtained from commercial concentrated stock solutions (Merck, Germany). The concentrations were determined by Atomic Absorption Spectrometry (AAS, Perkin Elmer, PinAAcle 900 F) using flame Atomic Absorption Spectroscopy (FAAS). 
Nutrients in plants: concentration and uptake

Five plants were randomly selected for estimation of grain and stalk nutrient content and uptake. Plants were rinsed with high purity double distilled water to remove soil particles/dust particles and were oven dried at $65 \square \mathrm{C}$ in a hot air oven, to a constant weight to determine biomass. Stalk, cobs, spathes, leaves and grains were separated and the biomass was expressed as stalk biomass (consisting of stalk, spathes and leaves) and grains were separated from cobs after drying and weighed for grain yield. Stalk and grains were then powdered using a mixer grinder fitted with stainless steel blades and preserved in polypropylene boxes for further analysis. Using the powdered samples, nutrient composition was determined using standard procedures. Powdered plant sample (one gram) was pre -digested with $5 \mathrm{ml}$ of concentrated $\mathrm{HNO} 3$ followed by digestion with di-acid mixture (HNO3:HClO4, 10:4). Volume of the digest was made up to $100 \mathrm{ml}$ with distilled water, filtered and preserved for total elemental analysis.

\section{Statistical analysis}

The experiment was laid out in a Randomised Complete Block design (RCBD) with 9 treatments and 3 replications. The ANOVA was performed using data analysis software. The LSD values at $\mathrm{P}=0.05$ were used to determine the significant differences between the treatment means.

\section{Results and Discussion}

Properties of soil and industrial waste composts

The nutrient concentrations of MEES compost and PS compost are summarized in Table 1. The MEES compost produced on transformation of industrial wastes as a result of its composting using urban solid waste recorded alkaline $\mathrm{pH}$ of 8.19 , higher electrical conductivity $\left(60.9 \mathrm{dSm}^{-1}\right)$. The compost was rich in $\mathrm{N}$ (2.28 per cent) and the organic carbon content was 41.2 per cent. Phosphorus and potassium concentrations were 0.46 per cent and 1.94 per cent respectively. The PS compost also recorded an alkaline $\mathrm{pH}$ of 7.99 and was rich in P content (3.29\%). Nitrogen and potassium contents were 1.93 and 0.81 per cent respectively. Both the composts followed same trend in micronutrients concentration: $\mathrm{Fe}>\mathrm{Mn}>\mathrm{Zn}>\mathrm{Cu}$, whereas major nutrients trend varied and it was $\mathrm{N}>\mathrm{K}>\mathrm{P}$ in MEES compost and $\mathrm{P}>\mathrm{N}>\mathrm{K}$ in primary sludge compost. The total $\mathrm{Ni}$ was $25.0 \mathrm{mg} \mathrm{kg}^{-1}$ and $57.6 \mathrm{mg} \mathrm{kg}^{-1}$ and $\mathrm{Cd}$ was $6.4 \mathrm{mg} \mathrm{kg}^{-1}$ and $6.6 \mathrm{mg} \mathrm{kg}^{-1}$ in MEES compost and PS compost respectively, while total $\mathrm{Pb}$ and $\mathrm{Cr}$ were below the detectable limits. The $\mathrm{C}: \mathrm{N}$ ratios of composts stabilised at 21.2 and 18.09 in PS compost and MEES compost respectively at the end of composting process.

The texture of the soil was sandy loam characterized under Kandic Paleustalf with an initial acidic $\mathrm{pH}$ (5.92), EC $0.08 \mathrm{dS} \mathrm{m}^{-1}$ and low organic carbon content of $3 \mathrm{~g} \mathrm{~kg}^{-1}$. The soil was low in available nitrogen $(131.71 \mathrm{~kg}$ $\left.\mathrm{ha}^{-1}\right)$, low in available $\mathrm{P}_{2} \mathrm{O}_{5}\left(19.89 \mathrm{~kg} \mathrm{ha}^{-1}\right)$, and high in available $\mathrm{K}_{2} \mathrm{O}\left(404.82 \mathrm{~kg} \mathrm{ha}^{-1}\right)$. The DTPA extractable $\mathrm{Fe}, \mathrm{Mn}, \mathrm{Zn}$ and $\mathrm{Cu}$ were $24.50,13.54,2.85$ and $1.11 \mathrm{mg} \mathrm{kg}^{-1}$, respectively. The CEC of the soil was $7.80 \mathrm{c}$ mol $(p+) \mathrm{kg}^{-1}$. Heavy metals were below the detectable limits.

\section{Soil pH, EC, OC and available nutrients}

Table 2 shows the effect of treatments on nutrient concentrations in the soil at the harvesting stage (135d). An increase in soil $\mathrm{pH}$ from 5.92 to 6.10 with the application of MEES compost and 5.92 to 7.15 with the application of PS compost was recorded, 
though the increase was not statistically different from the $\mathrm{pH}$ of the soil initially. Increased soil $\mathrm{pH}$ on application of MSW compost was reported as an advantage by Mkhabela and Warman, 2005.

The organic carbon content increased to 0.52 per cent and 0.49 per cent on application of MEES compost and PS compost respectively from an initial organic carbon content of 0.30 per cent. The increase in organic matter content on application of composts was not significantly different from the application of NPK fertilizer with farm yard manure. The application of FYM has contributed to the nominal increase in the organic carbon content in all the treatments. The application of farm yard manure, though contributes to a positive impact on soil organic carbon, additional benefits of decomposition results from the application of composted material to soils (Davis, 2002).

The available $\mathrm{N}, \mathrm{K}$, secondary nutrients and DTPA extractable iron showed statistically significant differences $(\mathrm{p}<0.05)$ as compared to the control soil. The concentration of $\mathrm{P}$ was higher on application of composts and it varied from 18.6 to $45.1 \mathrm{~kg} \mathrm{ha}^{-1}$. The heavy metals $\mathrm{Pb}, \mathrm{Cr}, \mathrm{Ni}$ and $\mathrm{Cd}$ were below the detectable limits. The status of available nutrients was more with the application of inorganic fertilizers along with full dose of FYM than the other treatments. Prasad and Sinha (1981) found that applying FYM (15.0 t $\left.\mathrm{ha}^{-1}\right)$ in conjunction with nitrogen, phosphorus and potassium (60-60-40 NPK kg ha ${ }^{-1}$ ) increased the accumulation of available phosphorus and potassium and levels of exchangeable calcium and magnesium in soil.

The soils treated with FYM alone, compost and waste materials were relatively low in its $\mathrm{N}$ content owing to $\mathrm{N}$ immobilisation because of increased microbial biomass (IglesiasJimenez and Alvarez, 1993; Crecchio et al.,
2004). Municipal solid waste compost is less effective in supplying $\mathrm{N}$ in the first year of application to the soil plant system than inorganic mineral fertilizers (Iglesias-Jimenez and Alvarez, 1993; Warman and Rodd, 1998; Eriksen et al., 1999). Application of industrial waste- MSW compost resulted in increased $\mathrm{P}$ concentration in soil. Municipal solid waste compost effectively supplies phosphorus to soil and the $\mathrm{P}$ concentration in soil increases with increased rates of application (IglesiasJimenez et al., 1993). Application of composts (MEES compost @ $10 \mathrm{t} \mathrm{ha}^{-1}$ and PS compost @10 $\mathrm{t} \mathrm{ha}^{-1}$ ) recorded marginal increase in $\mathrm{K}$ content than the initial soil $\mathrm{K}$. These results were in concordance with that of Giusquiani et al 1988 who reported increased soil $\mathrm{K}$ concentration with application of municipal solid waste compost. Application of composts resulted in no increase in sulphur content of soil compared to fertilizers. A poor response was noticed on addition of MSW compost compared to fertilizers (Shanmugam and Warman, 2004).

The iron content of soils were almost equal to the initial values with the application of MEES compost @ $10 \mathrm{t} \mathrm{ha} \mathrm{a}^{-1}$ and PS compost @ $10 \mathrm{t} \mathrm{ha}^{-1}$ and it did not tend to increase soil Fe concentrations. Similar finding in the case of municipal solid waste compost application to soil has been reported by Warman (2001) who showed that the application of MSW compost at 100 and $35-140 \mathrm{Mg} \mathrm{ha}^{-1}$ did not increase available soil $\mathrm{Fe}$ concentration. The contents of $\mathrm{Mn}, \mathrm{Zn}$ in soil were slightly higher than the initial and $\mathrm{Cu}$ content was lower on application of composts. The concentration of heavy metals (Ni, Cd) was below the detectable limits in the soil which could be attributed to the buffering capacity of the soil.

Insignificant increases in soil $\mathrm{pH}$ and organic carbon content was recorded with the application of composts. It could thus be observed that the available nutrient 
concentration in soil was slightly higher than the initial soil on application of organics like composts and waste materials. However, the increase was not more than that of the changes on application of synthetic fertilizers and FYM in the recommended dosage following the package of practices. Thus it becomes evident that the time taken for the mineralisation of nutrients from organic sources results in the poor increase in the concentration of nutrients in soil immediately after the application of composts and organics.

\section{Growth and yield of maize}

The growth and yield of maize inclusive of growth and yield parameters are summarised in Table 3. The growth and yield were statistically higher in maize plants grown on application of inorganics and organics following the package of practices i.e. NPK fertilizer+FYM@10 tha ${ }^{-1}$. Plant height and number of leaves at the time of harvest were significantly higher with the application of NPK fertilizer + FYM @ 10 tha $^{-1}$. The increased plant height and number of leaves with the application of 100\% NPK + FYM @ $10 \mathrm{t} \mathrm{ha}^{-1}$ may be attributed to the increased availability of nitrogen with the application of fertilizers. As $\mathrm{N}$ is one of the essential nutrients for growth and development of plants, an increase in the supply of nitrogen might have accelerated the activities of enzymes involved in the photosynthesis, carbohydrate metabolism, protein synthesis, synthesis of growth promoting substances, cell division and cell elongation. Being the constituent of chlorophyll, $\mathrm{N}$ increases the photosynthetic efficiency of crop which might have resulted in higher growth and development (Grazia et al., 2003; Suryavanshi et al., 2009).

The total yields of grain and straw were statistically higher in plants grown with the supply of both organics and inorganics. The application of NPK fertilizer + FYM @ 10 tha ${ }^{-1}$ resulted in a higher hundred seed weight of $26.82 \mathrm{~g}$, grain yield of $6341.47 \mathrm{~kg} \mathrm{ha}^{-1}$ and stalk yield of $11414.46 \mathrm{~kg} \mathrm{ha}$ when compared to all the other treatments. The increased dry matter accumulation in reproductive parts may be attributed to increased rate of metabolic processes due to increased available nutrients (Bangarwa et al., 1988). Application of MEES compost @ $10 \mathrm{t}$ $\mathrm{ha}^{-1}$ and PS compost @ $10 \mathrm{t} \mathrm{ha}^{-1}$ resulted in grain yields of 5517.48 and $5249.12 \mathrm{~kg} \mathrm{ha}^{-1}$ and stalk yields of 9931.47 and $9448.41 \mathrm{~kg} \mathrm{ha}^{-}$ ${ }^{1}$ respectively which were on par with each other. The application of composts alone has resulted in significantly lesser grain and stalk yields in comparison to the application of both inorganics and organics. When the composts were applied based on their nitrogen content along with urea and other phosphatic and potassic fertilizers, the grain and straw yields were almost on par with the application of NPK fertilizer + FYM @ 10 tha $^{-1}$. The increased growth and yield may be due to more nitrogen supply. Good response of maize to applied $\mathrm{N}$ could obviously be due to well developed root system and better translocation of photosynthates from leaves to the sink for better development of grains. The beneficial effects of higher nitrogen availability to maize ultimately reflected in higher grain yield. The increase in grain yield might probably be due to effective utilization of applied nutrients, increased sink capacity and nutrient uptake by the crop (Singh et al., 2000; Sekar et al., 2009).

\section{Nutrients content in maize}

Application of $100 \%$ NPK + FYM @ $10 \mathrm{t} \mathrm{ha}^{-1}$ was superior to all the other treatments, which was followed by treatments $\mathrm{T}_{2}(100 \%$ NPK + FYM @ $\left.5 \mathrm{t} \mathrm{ha}^{-1}\right), \mathrm{T}_{3}(50 \% \mathrm{~N}$ through MEES compost $+50 \% \mathrm{~N}$ through urea $+\mathrm{P}$ and $\mathrm{K}$ ) and $\mathrm{T}_{4}(50 \% \mathrm{~N}$ through PS compost $+50 \% \mathrm{~N}$ through urea $+\mathrm{P}$ and $\mathrm{K}$ ) (Table 4). There were 
significant differences in the contents of major and micronutrients, in maize grain except $\mathrm{Fe}$ where no significant difference was observed. The increase in $\mathrm{N}, \mathrm{P}$ and $\mathrm{K}$ contents with the application of $100 \%$ NPK + FYM @ $10 \mathrm{t} \mathrm{ha}^{-1}$ in maize grain may thus be attributed to the increased availability of soil $\mathrm{N}, \mathrm{P}$ and $\mathrm{K}$ content as it recorded a significant positive correlation with $\mathrm{N}, \mathrm{P}$ and $\mathrm{K}$ content in maize stalk (Table 6).

Since composts supply lower levels of N, P and $\mathrm{K}$ to soil compared to fertilizer treatments, it would result in low concentration of nutrients in grain. The data show that the compost did not supply $\mathrm{N}$ as effectively as the synthetic fertilizer + FYM. The lower grain $\mathrm{N}$ from the compost-applied plots with the application of MEES compost @ $10 \mathrm{tha}^{-1}$ and PS compost@10 $\mathrm{t} \mathrm{ha}^{-1}$ in comparison to 100 $\%$ NPK + FYM @ $10 \mathrm{t} \mathrm{ha}^{-1}$ indicate this inefficiency. Similar results have been obtained by Warman and Termeer (2005) in which they explained that the corn $\mathrm{N}$ content was more with the application of synthetic fertilizers than with the application of composts in the initial period of experiment. This could be attributed to the time taken for mineralisation of nutrients from composts, which is more than from fertilizers. Ca content was more in plant in non amended control plots than with addition of MSW compost as reported by Hampton et al (1994). He concluded that chelation of $\mathrm{Ca}$ by the return of organic molecules of municipal solid waste might have affected in the result.

The contents of micronutrients in maize grain were higher with the application of $100 \%$ NPK + FYM @ $10 \mathrm{t} \mathrm{ha}^{-1}$. Significant differences were observed between treatments in case of $\mathrm{Mn}, \mathrm{Zn}$ and $\mathrm{Cu}$ content with an exception in the iron content in maize grain. Application of 100\% NPK + FYM @ $10 \mathrm{t} \mathrm{ha}^{-1}$ recorded higher $\mathrm{Fe}, \mathrm{Mn}, \mathrm{Zn}$ and $\mathrm{Cu}$ content of 116.67, 75.33, 30.65 and $19.92 \mathrm{mg} \mathrm{kg}^{-1}$, respectively in maize grain. The $\mathrm{N}$ content in maize stalk ranged from 0.24 per cent with the application of FYM alone @ $10 \mathrm{t} \mathrm{ha}^{-1}$ to 0.57 per cent with the application of $100 \%$ NPK + FYM @ $10 \mathrm{t} \mathrm{ha}^{-1}$. Application of composts resulted in 0.35 per cent of total $\mathrm{N}$ content in maize stalk. Thus plant $\mathrm{N}$ content was lower in compost treated plots than when inorganics and organics were combined $\mathrm{T}_{1}(100 \% \mathrm{NPK}+$ FYM @ $\left.10 \mathrm{t} \mathrm{ha}^{-1}\right)$. This is attributed to the immobilisation of nitrogen occurring in soils on addition of fresh organic compost which provide as energy and nutrient source manifesting in microbial proliferation and increased microbial biomass. Municipal solid waste compost proved to be a poor $\mathrm{N}$ supplying amendment to corn and ryegrass where plant tissue $\mathrm{N}$ was lower in MSW treated plants compared to fertilizer treatments (Iglesias-Jimenez and Alvarez, 1993; Mamo et al., 1999).

Application of MEES compost @ $10 \mathrm{t} \mathrm{ha}^{-1}$ and PS compost @ $10 \mathrm{t} \mathrm{ha}^{-1}$ were on par with each other and recorded 0.10 and 0.11 per cent of $P$ and 0.96 and 0.97 per cent of $K$ respectively in the stalk. This was on par with the application of 100\% NPK + FYM @ $10 \mathrm{t} \mathrm{ha}^{-1}$ ) and 100\% $\mathrm{NPK}+\mathrm{FYM} @ 5 \mathrm{t} \mathrm{ha}^{-1}$. Some researchers observed that MSW compost was a source of $\mathrm{P}$, however it was low (Iglesias-Jimenez et al., 1993). Bengtson and Cornette (1973) indicated that the addition of composts to soil does not produce significant changes in plant phosphorus concentration; producing, at most, slight increase in the amount of this nutrient when high doses of compost were used (Gallardo-Lara and Nogales, 1987).

There was significant difference between all the treatments with respect to the iron content in maize stalk. Application of MEES compost @ $10 \mathrm{t} \mathrm{ha}^{-1}$ and PS compost @ $10 \mathrm{t} \mathrm{ha}^{-1}$ recorded $330.56 \mathrm{mg} \mathrm{kg}^{-1}$ of iron. There were no significant differences between treatments in case of $\mathrm{Zn}$ and $\mathrm{Cu}$ content of maize stalk. 
The heavy metals content was below the detectable limits in all the cases.

\section{Nutrient uptake by maize}

Significant differences were observed with the uptake of nutrients by maize grain. The trend was similar to that of nutrients content in maize grain. Application of MEES compost @ $10 \mathrm{t} \mathrm{ha}^{-1}$ and PS compost @ $10 \mathrm{t} \mathrm{ha}^{-1}$ resulted in $\mathrm{N}, \mathrm{P}$ and $\mathrm{K}$ uptake of 52.61, 15.21 and $21.76 \mathrm{~kg} \mathrm{ha}^{-1}$ and $48.45,13.81$, and $18.80 \mathrm{~kg}$ $\mathrm{ha}^{-1}$ respectively. The $\mathrm{Ca}, \mathrm{Mg}$ and $\mathrm{S}$ uptake by grain also followed the same trend. Application of 100\% NPK+ FYM @ $10 \mathrm{t} \mathrm{ha}^{-1}$ recorded higher $\mathrm{Ca}, \mathrm{Mg}$ and $\mathrm{S}$ uptake compared to other. Application of FYM alone (FYM @ $10 \mathrm{t} \mathrm{ha}^{-1}$ ) recorded lower Ca, Mg and $\mathrm{S}$ uptake when compared to other treatments.

Application of 100\% NPK + FYM @ $10 \mathrm{t} \mathrm{ha}^{-1}$ recorded higher uptake of major as well as micronutrients and it recorded 737.21, 477.70, 195.04 and $126.37 \mathrm{~g} \mathrm{ha}^{-1} \mathrm{Fe}, \mathrm{Mn}, \mathrm{Zn}$ and $\mathrm{Cu}$ respectively. All the treatments recorded higher uptake than application of FYM @10 t $\mathrm{ha}^{-1}$ which recorded relatively lower uptakes of 164.06, 111.93, 81.93 and $52.42 \mathrm{~g} \mathrm{ha}^{-1} \mathrm{Fe}$, $\mathrm{Mn}, \mathrm{Zn}$ and $\mathrm{Cu}$ respectively. The uptake of all the nutrients from the plots where composts were applied were not statistically different from the plots where FYM and raw wastes were applied, This may be due to a lower phytoavailability of applied nutrients from organic sources than the inorganic sources resulting in lesser yield in compost applied plots, thereby reduced nutrient uptake. In all the cases, nutrient uptake by maize grain on application of composts ( $\mathrm{T}_{6}$ : MEES compost @ $10 \mathrm{t} \mathrm{ha}^{-1}$ and $\mathrm{T}_{7}$ : PS compost @ $10 \mathrm{t} \mathrm{ha}^{-1}$ ) were on par with each other. No significant difference was observed with respect to the uptake of iron by maize grain. Warman et al., (2004) reported similar findings in case of municipal solid waste compost application. They reported that MSW compost was found to have a weak effect on soil available Fe with no effect on plant uptake.

Table.1 Nutrient composition of MEES compost and PS compost

\begin{tabular}{|l|c|c|}
\hline Parameter & MEES Compost & PS Compost \\
\hline $\mathrm{pH}(1: 10)$ & 8.19 & 7.88 \\
\hline $\mathrm{EC}\left(\mathrm{dSm}^{-1}\right)$ & 60.90 & 6.99 \\
\hline $\mathrm{OC}(\%)$ & 41.29 & 41.11 \\
\hline $\mathrm{N}(\%)$ & 2.282 & 1.932 \\
\hline $\mathrm{C}: \mathrm{N}$ & 18.09 & 21.28 \\
\hline $\mathrm{P}(\%)$ & 0.467 & 3.273 \\
\hline $\mathrm{K}$ & 1.940 & 0.810 \\
\hline Fe $\left(\mathrm{mg} \mathrm{kg}^{-1}\right)$ & 709.20 & 3013.00 \\
\hline $\mathrm{Mn}\left(\mathrm{mg} \mathrm{kg}^{-1}\right)$ & 235.33 & 324.00 \\
\hline $\mathrm{Zn}\left(\mathrm{mg} \mathrm{kg}^{-1}\right)$ & 152.63 & 265.00 \\
\hline $\mathrm{Cu}\left(\mathrm{mg} \mathrm{kg}^{-1}\right)$ & 73.33 & 196.50 \\
\hline $\mathrm{Ni}\left(\mathrm{mg} \mathrm{kg}^{-1}\right)$ & 25.00 & 57.60 \\
\hline $\mathrm{Cd}\left(\mathrm{mg} \mathrm{kg}^{-1}\right)$ & 6.4 & 6.6 \\
\hline Humic Acid $(\%)$ & 6.47 & 7.00 \\
\hline Fulvic acid $(\%)$ & 3.03 & 2.27 \\
\hline Humic acid index & 2.13 & 3.10 \\
\hline E $/ \mathrm{E}_{6}$ & 5.15 & 4.13 \\
\hline
\end{tabular}

$* \mathrm{~Pb}$ and $\mathrm{Cr}$ were below the detectable limits 
Table.2 Effect of enzyme industry biosolid composts on pH, EC, OC and available nutrients in soil

\begin{tabular}{|c|c|c|c|c|c|c|c|c|c|c|c|c|c|}
\hline \multirow[t]{2}{*}{ Treatment } & \multirow{2}{*}{$\begin{array}{l}\mathbf{p H} \\
(1: 2.5)\end{array}$} & \multirow{2}{*}{$\begin{array}{l}\text { EC } \\
\mathrm{dSm}^{-1}\end{array}$} & \multirow{2}{*}{$\begin{array}{r}\text { OC } \\
\%\end{array}$} & $\mathbf{N}$ & $\mathbf{P}$ & $\mathbf{K}$ & $\mathbf{C a}$ & Mg & $\mathbf{S}$ & $\mathbf{F e}$ & Mn & $\mathbf{Z n}$ & $\mathrm{Cu}$ \\
\hline & & & & \multicolumn{3}{|c|}{$\mathrm{kg} \mathrm{ha}^{-1}$} & \multicolumn{2}{|c|}{ cmol (+) $\mathrm{kg}^{-1}$} & \multicolumn{5}{|c|}{$\mathrm{mg} \mathrm{kg}^{-1}$} \\
\hline T1 & 5.75 & 0.05 & 0.52 & 175.23 & 45.16 & 322.88 & 4.87 & 2.04 & 15.54 & 33.27 & 10.23 & 8.15 & 1.027 \\
\hline $\mathbf{T 2}$ & 5.74 & 0.07 & 0.44 & 170.88 & 40.53 & 309.12 & 3.90 & 1.88 & 12.87 & 29.15 & 9.96 & 7.01 & 1.018 \\
\hline T3 & 6.23 & 0.06 & 0.48 & 164.04 & 35.83 & 295.81 & 3.50 & 1.46 & 11.89 & 26.91 & 8.83 & 4.37 & 0.875 \\
\hline T4 & 5.71 & 0.06 & 0.49 & 151.29 & 41.50 & 283.81 & 3.38 & 1.94 & 12.29 & 28.19 & 9.17 & 5.27 & 1.027 \\
\hline T5 & 6.35 & 0.04 & 0.50 & 119.83 & 18.62 & 215.70 & 2.60 & 1.18 & 8.42 & 22.10 & 8.67 & 3.07 & 0.908 \\
\hline T6 & 6.10 & 0.14 & 0.52 & 144.47 & 28.59 & 264.73 & 2.45 & 1.00 & 6.05 & 19.58 & 8.48 & 5.27 & 0.877 \\
\hline T7 & 7.15 & 0.08 & 0.49 & 132.15 & 30.98 & 241.37 & 2.70 & 1.16 & 9.96 & 23.54 & 8.77 & 3.14 & 0.709 \\
\hline T8 & 6.72 & 0.14 & 0.50 & 123.56 & 30.59 & 229.76 & 2.38 & 0.87 & 5.54 & 18.41 & 6.19 & 2.03 & 0.955 \\
\hline T9 & 6.71 & 0.11 & 0.48 & 120.70 & 24.32 & 220.16 & 2.32 & 0.64 & 5.26 & 12.19 & 4.75 & 1.61 & 0.810 \\
\hline SEm \pm & 0.34 & 0.01 & 0.10 & 9.06 & 7.04 & 22.56 & 0.29 & 0.19 & 2.25 & 3.40 & 1.56 & 1.43 & 0.146 \\
\hline CD@ @\% & NS & 0.04 & NS & 27.16 & NS & 67.64 & 0.87 & 0.56 & 6.76 & 10.19 & NS & NS & NS \\
\hline Soil(Initial) & 5.92 & 0.08 & 0.30 & 131.71 & 19.89 & 404.32 & 3.28 & 2.52 & 11.50 & 24.50 & 13.54 & 2.85 & 1.11 \\
\hline
\end{tabular}

$\mathrm{T}_{1}:$ POP (100\% NPK + FYM @ $\left.10 \mathrm{t} \mathrm{ha}^{-1}\right), \mathrm{T}_{2}: 100 \% \mathrm{NPK}+\mathrm{FYM} @ 5 \mathrm{t} \mathrm{ha}^{-1}, \mathrm{~T}_{3}: 50 \% \mathrm{~N}$ through MEES compost $+50 \% \mathrm{~N}$ through urea $+\mathrm{P}$ and $\mathrm{K}, \mathrm{T}_{4}: 50 \% \mathrm{~N}$ through PS compost+ $50 \% \mathrm{~N}$ through urea $+\mathrm{P}$ and $\mathrm{K}, \mathrm{T}_{5}: \mathrm{FYM} @ 10 \mathrm{t} \mathrm{ha}^{-1}, \mathrm{~T}_{6}$ : MEES compost @ $10 \mathrm{tha}^{-1}, \mathrm{~T}_{7}$ : $\mathrm{PS}$ compost @ $10 \mathrm{t} \mathrm{ha}^{-1}, \mathrm{~T}_{8}: 50 \% \mathrm{~N}$ through MEES + $50 \% \mathrm{~N}$ through FYM, $\mathrm{T}_{9}: 50 \% \mathrm{~N}$ through PS + $50 \% \mathrm{~N}$ through FYM

Table.3 Effect of enzyme industry biosolid composts on growth parameters, grain and stalk yields of maize

\begin{tabular}{|c|c|c|c|c|c|}
\hline \multirow[t]{2}{*}{ Treatments } & $\begin{array}{l}\text { Plant } \\
\text { height }\end{array}$ & $\begin{array}{c}\text { Number of } \\
\text { leaves }\end{array}$ & $\begin{array}{l}\text { Hundred Seed } \\
\text { weight }\end{array}$ & $\begin{array}{l}\text { Grain } \\
\text { Yield }\end{array}$ & $\begin{array}{l}\text { Stalk } \\
\text { Yield }\end{array}$ \\
\hline & $(\mathbf{c m})$ & & (g) & \multicolumn{2}{|c|}{$\left(\mathrm{kg} \mathrm{ha}^{-1}\right)$} \\
\hline $\mathrm{T}_{1}$ & 188.00 & 9.96 & 26.82 & 6341.47 & 11414.46 \\
\hline $\mathrm{T}_{2}$ & 180.37 & 9.63 & 24.36 & 6064.03 & 10915.25 \\
\hline $\mathrm{T}_{3}$ & 172.17 & 9.28 & 23.60 & 5964.03 & 10735.25 \\
\hline $\mathrm{T}_{4}$ & 146.13 & 8.16 & 23.56 & 5756.57 & 10361.83 \\
\hline $\mathrm{T}_{5}$ & 113.13 & 6.75 & 17.33 & 4254.00 & 7657.20 \\
\hline $\mathrm{T}_{6}$ & 139.53 & 7.88 & 22.35 & 5517.48 & 9931.47 \\
\hline $\mathrm{T}_{7}$ & 133.40 & 7.62 & 18.47 & 5249.12 & 9448.41 \\
\hline $\mathrm{T}_{8}$ & 127.47 & 7.36 & 17.84 & 4842.83 & 8717.10 \\
\hline $\mathrm{T}_{9}$ & 118.57 & 6.98 & 17.33 & 4509.50 & 8117.10 \\
\hline Sem \pm & 4.85 & 0.25 & 2.03 & 106.36 & 191.45 \\
\hline C.D. at $5 \%$ & 14.13 & 0.72 & 6.07 & 318.88 & 573.99 \\
\hline
\end{tabular}

$\mathrm{T}_{1}:$ POP (100\% NPK + FYM @ $\left.10 \mathrm{t} \mathrm{ha}^{-1}\right) ; \mathrm{T}_{2}: 100 \% \mathrm{NPK}+\mathrm{FYM} @ 5 \mathrm{t} \mathrm{ha}^{-1} ; \mathrm{T}_{3}: 50 \% \mathrm{~N}$ through MEES compost $+50 \%$ $\mathrm{N}$ through urea $+\mathrm{P}$ and $\mathrm{K} ; \mathrm{T}_{4}: 50 \% \mathrm{~N}$ through PS compost $+50 \% \mathrm{~N}$ through urea $+\mathrm{P}$ and $\mathrm{K} ; \mathrm{T}_{5}: \mathrm{FYM} @ 10 \mathrm{t} \mathrm{ha}^{-1} ; \mathrm{T}_{6}$ : MEES compost @ $10 \mathrm{t} \mathrm{ha}^{-1} ; \mathrm{T}_{7}$ : PS compost @ $10 \mathrm{t} \mathrm{ha}^{-1} ; \mathrm{T}_{8}: 50 \% \mathrm{~N}$ through MEES + $50 \% \mathrm{~N}$ through FYM; $\mathrm{T}_{9}: 50 \% \mathrm{~N}$ through PS + $50 \% \mathrm{~N}$ through FYM 
Table.4 Effect of enzyme industry biosolid composts on nutrients content in maize grain and stalk

\begin{tabular}{|c|c|c|c|c|c|c|c|c|c|c|}
\hline \multirow{3}{*}{ Treatments } & \multicolumn{10}{|c|}{ Grain } \\
\hline & $\mathbf{N}$ & $\mathbf{P}$ & $\mathbf{K}$ & $\mathrm{Ca}$ & Mg & $\mathbf{S}$ & $\mathrm{Fe}$ & Mn & $\mathbf{Z n}$ & $\mathrm{Cu}$ \\
\hline & \multicolumn{6}{|c|}{$\%$} & \multicolumn{4}{|c|}{$\mathrm{mg} \mathrm{kg}^{-1}$} \\
\hline $\mathrm{T}_{1}$ & 1.52 & 0.35 & 0.57 & 0.58 & 0.51 & 0.36 & 116.67 & 75.33 & 30.65 & 19.92 \\
\hline $\mathrm{T}_{2}$ & 1.22 & 0.32 & 0.47 & 0.55 & 0.47 & 0.33 & 92.33 & 62.20 & 28.05 & 18.22 \\
\hline $\mathrm{T}_{3}$ & 1.14 & 0.30 & 0.43 & 0.47 & 0.45 & 0.31 & 74.67 & 58.00 & 23.13 & 15.02 \\
\hline $\mathrm{T}_{4}$ & 1.13 & 0.30 & 0.41 & 0.44 & 0.42 & 0.31 & 82.33 & 48.80 & 22.10 & 14.36 \\
\hline $\mathrm{T}_{5}$ & 0.56 & 0.14 & 0.30 & 0.34 & 0.25 & 0.14 & 38.33 & 26.20 & 19.02 & 12.36 \\
\hline $\mathrm{T}_{6}$ & 0.95 & 0.28 & 0.39 & 0.41 & 0.39 & 0.29 & 66.33 & 45.00 & 21.35 & 13.86 \\
\hline $\mathrm{T}_{7}$ & 0.92 & 0.26 & 0.36 & 0.39 & 0.32 & 0.27 & 72.67 & 40.00 & 21.35 & 13.86 \\
\hline $\mathrm{T}_{8}$ & 0.91 & 0.24 & 0.33 & 0.36 & 0.30 & 0.25 & 57.33 & 36.00 & 21.21 & 13.78 \\
\hline $\mathrm{T}_{9}$ & 0.88 & 0.21 & 0.31 & 0.35 & 0.26 & 0.21 & 58.67 & 30.00 & 19.36 & 12.58 \\
\hline Sem \pm & 0.07 & 0.03 & 0.03 & 0.05 & 0.05 & 0.03 & 17.98 & 9.98 & 2.12 & 0.79 \\
\hline \multirow[t]{2}{*}{ C.D. at $5 \%$} & 0.22 & 0.09 & 0.08 & 0.16 & 0.15 & 0.09 & NS & 29.91 & 6.35 & 2.36 \\
\hline & \multicolumn{10}{|c|}{ Stalk } \\
\hline $\mathrm{T}_{1}$ & 0.57 & 0.11 & 1.60 & 1.02 & 0.51 & 0.34 & 474.66 & 67.93 & 28.66 & 25.43 \\
\hline $\mathrm{T}_{2}$ & 0.53 & 0.11 & 1.49 & 0.92 & 0.40 & 0.31 & 434.40 & 63.08 & 25.84 & 24.89 \\
\hline $\mathrm{T}_{3}$ & 0.50 & 0.10 & 1.40 & 0.88 & 0.36 & 0.30 & 358.11 & 59.55 & 24.56 & 21.02 \\
\hline $\mathrm{T}_{4}$ & 0.45 & 0.10 & 1.26 & 0.87 & 0.35 & 0.28 & 342.22 & 53.59 & 24.31 & 20.08 \\
\hline $\mathrm{T}_{5}$ & 0.24 & 0.06 & 0.67 & 0.40 & 0.23 & 0.17 & 294.54 & 28.45 & 16.06 & 17.29 \\
\hline $\mathrm{T}_{6}$ & 0.35 & 0.10 & 0.96 & 0.81 & 0.33 & 0.26 & 330.56 & 40.80 & 22.77 & 19.40 \\
\hline $\mathrm{T}_{7}$ & 0.35 & 0.11 & 0.97 & 0.76 & 0.29 & 0.21 & 330.56 & 41.02 & 21.24 & 19.40 \\
\hline $\mathrm{T}_{8}$ & 0.28 & 0.09 & 0.77 & 0.70 & 0.27 & 0.20 & 328.45 & 32.64 & 19.70 & 19.28 \\
\hline $\mathrm{T}_{9}$ & 0.25 & 0.08 & 0.70 & 0.60 & 0.24 & 0.17 & 299.84 & 29.77 & 16.89 & 17.60 \\
\hline Sem \pm & 0.01 & 0.02 & 0.03 & 0.09 & 0.03 & 0.03 & 32.80 & 1.13 & 3.38 & 2.23 \\
\hline C.D. at $5 \%$ & 0.03 & NS & 0.08 & 0.26 & 0.08 & 0.10 & 98.34 & 3.39 & NS & NS \\
\hline
\end{tabular}



Table.5 Effect of enzyme industry biosolid composts on nutrients uptake by maize grain and stalk

\begin{tabular}{|c|c|c|c|c|c|c|c|c|c|c|}
\hline \multirow{3}{*}{ Treatments } & \multicolumn{10}{|c|}{ Grain } \\
\hline & $\mathbf{N}$ & $\mathbf{P}$ & $\mathbf{K}$ & Ca & Mg & $\mathbf{S}$ & Fe & Mn & $\mathbf{Z n}$ & $\mathbf{C u}$ \\
\hline & \multicolumn{6}{|c|}{$\mathrm{kg} \mathrm{ha}^{-1}$} & \multicolumn{4}{|c|}{$\mathrm{g} \mathrm{ha}^{-1}$} \\
\hline $\mathrm{T}_{1}$ & 96.39 & 22.58 & 36.37 & 36.70 & 32.31 & 23.52 & 737.21 & 477.70 & 195.04 & 126.37 \\
\hline $\mathrm{T}_{2}$ & 73.52 & 19.37 & 28.59 & 33.69 & 28.48 & 20.18 & 557.00 & 374.61 & 170.48 & 110.55 \\
\hline $\mathrm{T}_{3}$ & 68.08 & 17.75 & 25.79 & 27.84 & 27.06 & 18.49 & 447.29 & 345.88 & 137.65 & 89.68 \\
\hline $\mathrm{T}_{4}$ & 65.09 & 17.49 & 23.56 & 25.33 & 24.16 & 18.22 & 472.86 & 281.61 & 126.71 & 82.76 \\
\hline $\mathrm{T}_{5}$ & 23.85 & 6.00 & 12.62 & 14.39 & 10.42 & 6.25 & 164.06 & 111.93 & 81.93 & 52.42 \\
\hline $\mathrm{T}_{6}$ & 52.61 & 15.21 & 21.76 & 22.74 & 21.61 & 15.84 & 369.00 & 246.41 & 117.83 & 76.41 \\
\hline $\mathrm{T}_{7}$ & 48.45 & 13.81 & 18.80 & 20.10 & 16.87 & 14.38 & 371.82 & 211.40 & 111.86 & 72.85 \\
\hline $\mathrm{T}_{8}$ & 44.13 & 11.68 & 16.14 & 17.41 & 14.60 & 12.17 & 277.41 & 175.99 & 102.50 & 66.83 \\
\hline $\mathrm{T}_{9}$ & 39.75 & 9.36 & 14.09 & 15.27 & 11.51 & 9.75 & 259.98 & 133.98 & 87.00 & 56.62 \\
\hline Sem \pm & 4.25 & 2.52 & 1.58 & 3.23 & 2.60 & 2.63 & 96.90 & 56.83 & 11.46 & 4.76 \\
\hline \multirow[t]{2}{*}{ C.D. at $5 \%$} & 12.75 & 7.56 & 4.73 & 9.67 & 7.79 & 7.87 & 290.53 & 170.37 & 34.35 & 14.28 \\
\hline & \multicolumn{10}{|c|}{ Stalk } \\
\hline $\mathrm{T}_{1}$ & 65.60 & 11.30 & 182.75 & 118.88 & 57.81 & 38.77 & 5436.27 & 775.08 & 333.32 & 292.26 \\
\hline $\mathrm{T}_{2}$ & 58.26 & 10.77 & 162.29 & 101.99 & 44.03 & 34.17 & 4751.70 & 688.32 & 285.95 & 272.41 \\
\hline $\mathrm{T}_{3}$ & 54.13 & 10.75 & 150.78 & 93.44 & 39.09 & 32.47 & 3836.85 & 639.50 & 262.00 & 225.18 \\
\hline $\mathrm{T}_{4}$ & 46.94 & 9.75 & 130.75 & 92.10 & 35.48 & 28.99 & 3531.90 & 554.56 & 258.23 & 207.29 \\
\hline $\mathrm{T}_{5}$ & 18.41 & 6.53 & 51.29 & 31.59 & 17.64 & 12.50 & 2283.71 & 217.53 & 134.72 & 134.03 \\
\hline $\mathrm{T}_{6}$ & 34.32 & 9.40 & 95.60 & 80.08 & 32.52 & 25.93 & 3284.27 & 405.45 & 224.53 & 192.75 \\
\hline $\mathrm{T}_{7}$ & 32.84 & 9.34 & 91.47 & 72.69 & 27.63 & 20.24 & 3117.96 & 387.95 & 203.82 & 182.99 \\
\hline $\mathrm{T}_{8}$ & 24.04 & 7.58 & 66.97 & 61.51 & 23.53 & 17.53 & 2856.99 & 284.03 & 172.47 & 167.68 \\
\hline $\mathrm{T}_{9}$ & 20.49 & 6.98 & 57.07 & 49.28 & 19.79 & 13.81 & 2424.81 & 242.04 & 138.17 & 142.31 \\
\hline Sem \pm & 1.17 & 2.04 & 3.27 & 13.28 & 2.78 & 3.12 & 319.36 & 13.87 & 42.81 & 23.22 \\
\hline C.D. at $5 \%$ & 3.52 & NS & 9.81 & 39.80 & 8.33 & 9.34 & 957.48 & 41.60 & 128.35 & 69.61 \\
\hline
\end{tabular}


Table.6 Correlation between NPK in soil, NPK content, NPK uptake and yield of maize

\begin{tabular}{|c|c|c|c|c|c|c|c|c|c|c|c|c|c|c|c|c|}
\hline & Yield & Soil N & Soil $\mathbf{P}_{2} \mathbf{O}_{5}$ & Soil $\mathrm{K}_{2} \mathrm{O}$ & $\begin{array}{c}\text { Grain } \\
\mathbf{N}\end{array}$ & $\begin{array}{c}\text { Grain } \\
\text { P }\end{array}$ & $\begin{array}{c}\text { Grain } \\
\text { K }\end{array}$ & Stalk N & Stalk P & Stalk K & $\begin{array}{c}\text { Grain } \\
\mathbf{N}\end{array}$ & Grain P & $\begin{array}{c}\text { Grain } \\
\text { K }\end{array}$ & Stalk N & $\begin{array}{c}\text { Stalk } \\
\mathbf{P}\end{array}$ & $\begin{array}{c}\text { Stalk } \\
\text { K }\end{array}$ \\
\hline & & & & & \multicolumn{6}{|c|}{ Content (c) } & \multicolumn{6}{|c|}{ Uptake (up) } \\
\hline Yield & 1 & & & & & & & & & & & & & & & \\
\hline Soil N & $0.846 * *$ & 1 & & & & & & & & & & & & & & \\
\hline Soil $\mathrm{P}_{2} \mathrm{O}_{5}$ & $0.604 * *$ & $0.558 * *$ & 1 & & & & & & & & & & & & & \\
\hline Soil $\mathrm{K}_{2} \mathrm{O}$ & $0.645 * *$ & $0.620 * *$ & $0.468 *$ & 1 & & & & & & & & & & & & \\
\hline Grain N-c & $0.820 * *$ & $0.579 * *$ & $0.440^{*}$ & $0.382 *$ & 1 & & & & & & & & & & & \\
\hline Grain P-c & 0.299 & 0.316 & 0.174 & 0.248 & 0.026 & 1 & & & & & & & & & & \\
\hline Grain K-c & $0.851 * *$ & $0.763 * *$ & $0.583 * *$ & $0.533 * *$ & $0.757 * *$ & 0.172 & 1 & & & & & & & & & \\
\hline Stalk N-c & $0.959 * *$ & $0.853 * *$ & $0.647 * *$ & $0.625 * *$ & $0.820 * *$ & 0.230 & $0.876^{* *}$ & 1 & & & & & & & & \\
\hline Stalk P - c & 0.340 & 0.208 & 0.199 & $0.570 * *$ & 0.339 & -0.401 & 0.308 & 0.289 & 1 & & & & & & & \\
\hline Stalk K-c & $0.959 * *$ & $0.853 * *$ & $0.647 * *$ & $0.625 * *$ & $0.820 * *$ & 0.230 & $0.876^{* *}$ & 0.265 & 0.289 & 1 & & & & & & \\
\hline Grain $\mathbf{N}$ up & $0.901 * *$ & $0.706^{* *}$ & $0.507 * *$ & $0.476 * *$ & $0.979 * *$ & 0.134 & $0.832 * *$ & $0.903 * *$ & 0.314 & $0.903 * *$ & 1 & & & & & \\
\hline Grain P up & $0.408^{*}$ & $0.419 *$ & 0.256 & 0.324 & 0.114 & $0.987 * *$ & 0.283 & 0.348 & 0.353 & 0.348 & 0.235 & 1 & & & & \\
\hline Grain K up & $0.915 * *$ & $0.837 * *$ & $0.607 * *$ & $0.588 * *$ & $0.782 * *$ & 0.265 & $0.984 * *$ & $0.926 * *$ & 0.281 & $0.926 * *$ & $0.872 * *$ & $0.380 *$ & 1 & & & \\
\hline Stalk N up & $0.965 * *$ & $0.878 * *$ & $0.638 * *$ & $0.632 * *$ & $0.812 * *$ & 0.286 & $0.883 * *$ & $0.995^{* *}$ & 0.260 & $0.995 * *$ & $0.904 * *$ & $0.404 *$ & $0.940 * *$ & 1 & & \\
\hline Stalk P up & $0.504 * *$ & 0.305 & 0.247 & $0.468 *$ & $0.423^{*}$ & -0.006 & $0.500 * *$ & $0.495 * *$ & 0.248 & $0.495 * *$ & $0.459 *$ & 0.075 & $0.508 * *$ & $0.492 * *$ & 1 & \\
\hline Stalk K up & $0.965 * *$ & $0.878 * *$ & $0.638 * *$ & $0.632 * *$ & $0.812 * *$ & 0.286 & $0.883 * *$ & $0.995 * *$ & 0.260 & $0.995 * *$ & $0.904 * *$ & $0.404 *$ & $0.940 * *$ & 0.265 & $0.492 * *$ & 1 \\
\hline
\end{tabular}

** Correlation is significant at the 0.01 level, * Correlation is significant at the 0.05 level (2-tailed). 
There were significant differences in the uptake of nutrients by maize stalk, with an exception in uptake of $\mathrm{P}$, which exhibited no significant difference. There were significant differences in $\mathrm{N}$ and $\mathrm{K}$ uptake by maize stalk and this may be attributed to the content of major nutrients in maize stalk. The soil $\mathrm{N}$ and $\mathrm{K}$ recorded a significant positive correlation with $\mathrm{N}$ and $\mathrm{K}$ content in maize stalk, whereas soil $\mathrm{P}$ did not record a significant correlation.

Application of MEES compost @ $10 \mathrm{t} \mathrm{ha}^{-1}$ and PS compost @ $10 \mathrm{t} \mathrm{ha}^{-1}$ recorded similar uptake of secondary nutrients (80.08 and $72.69,32.52$ and $27.63,20.24$ and $25.93 \mathrm{~kg}$ $\mathrm{ha}^{-1}$ of $\mathrm{Ca}, \mathrm{Mg}$ and $\mathrm{S}$ respectively). The uptake of micronutrients by stalk also followed the same trend as that of micronutrients content. Application of $100 \%$ $\mathrm{NPK}+\mathrm{FYM} @ 10 \mathrm{t} \mathrm{ha}^{-1}$ recorded higher uptake of micronutrients (5436.27, 775.08, 333.32 and $292.26 \mathrm{~g} \mathrm{ha}^{-1}$ of $\mathrm{Fe} \mathrm{Mn} \mathrm{Zn}$ and $\mathrm{Cu}$ respectively). Micronutrients uptake of 3117.96, 387.95, 203.82 and $182.99 \mathrm{~g} \mathrm{ha}^{-1}$ of $\mathrm{Fe}, \mathrm{Mn}, \mathrm{Zn}$ and $\mathrm{Cu}$, respectively was recorded with the application of PS compost @ 10 tha

1 which was higher in uptake than the application of farm yard manure alone (Treatment $\mathrm{T}_{5}$ : FYM @ $10 \mathrm{t} \mathrm{ha}^{-1}$ ). Increased uptake of $\mathrm{Cu}$ was observed in corn, potato, squash, basil and Swiss chard on growing in soils amended with MSW compost (Warman and Rodd, 1998).

The present work shows that the enzyme industrial waste - municipal solid waste composts are good sources of plant nutrients. It can be concluded that the application of composts resulted in insignificant increases in soil $\mathrm{pH}$ and organic carbon content. The available nutrient concentration in soil was slightly higher than the initial soil on application of organics like composts and waste materials. Though the nutrient supply was not as that supplied by the application of recommended dosage of inorganic fertilizers, the effects on crop growth and yield by applying composts were certainly better than the application of farmyard manure as well as waste materials alone. Though heavy metal concentration was observed in composts, application of composts did not add heavy metal concentration in the soil and maize in this study.

It is therefore concluded that the application of composts produced out of enzyme industrial waste and municipal solid waste does not necessarily cause short term problems to plants. However, in the long term, the use of these composts may cause accumulation of heavy metals in the soil and plants and heavy metal pollution due to the application of MSW compost as organic fertilizers is of great concern. The residual effects of MSW compost on the subsequent crops must be evaluated as excessive contamination would affect heavy metal accumulation in plant tissues. Therefore, long term studies are needed to improve our understanding on the effects of application of enzyme industrial waste - municipal solid wastes composts on heavy metal accumulation in the soil. Thus, further research is necessary to confirm benefits of compost, optimization of dose and effects of heavy metals on crop yield and quality.

\section{Acknowledgements}

We are grateful to all the Ph.D. and M.Sc. student researchers who assisted in conducting the research.

\section{References}

Baldantoni, D., Leone, A., Iovieno, P., Morra, L., Zaccardelli, M., and Alfani, A., 2010. Total and available soil trace element concentrations in two Mediterranean agricultural systems treated with municipal waste compost or conventional mineral fertilizers. 
Chemosphere. 80: 1006-1013.

Bangarwa, A. S., Katron, M. S., and Singh, K.P., 1988. Effect of plant density, level and proportion of nitrogen fertilization on growth, yield and yield components of winter maize. Indian J. Agric. Sci. 58 (11): 854-858.

Barral, M., Paradelo, R., Moldes, A.B., Daurguer, M., and Freire, F.D., 2009. Utilization of MSW compost for organic matter conservation in agricultural soil of NW Spain. Resour. Conserv. Recy. 53: 529-534.

Bengtson, G. W., and Cornette, J. J., 1973. Disposal ofcomposted municipal waste in a plantationof young slash pine: Effects on soil and trees. Journal of Environmental Quality. 2: 441-444.

Bray, R. H., and Kurtz, L. T., 1945. Determination of total organic and available forms of phosphorus in soils. Soil Science. 59: 39-45.

Cala, V., Cases, M. A. and Walter, I., 2005. Biomass production and heavy metal content of Rosmarinus officinalis grown on organic waste-amended soil. Journal of Arid Environment. 62: 401-412.

Carbonell, G., Bravo, J. C., López-Mancisidor, P., Pro, J., Fernandez, C., and Tarazona, J.V., 2009. Distribution, fractionation and mobility assessment of heavy metals in a spiked soil using a multispecies-soil system. Spanish Journal Agricultural Research. 79: 629-637.

Crecchio, C., Curci, M., Pizzigallo, M., Ricciuti, P. and Ruggiero, P., 2004. Effects of municipal solid waste compost amendments on soil enzymeactivities and bacterial genetic diversity. Soil Biology and Biochemistry, 36: 1595-1605.

Davis, J., 2002. Livestock Manure Impacts on Carbon Cycling. http://www.colostate. edu/Depts/SoilCrop/extension/Newslett ers/2002/May/Mayweb/may09.html.

Eriksen, G., Coale, F., and Bollero, G., 1999. Soil nitrogen dynamics and maize production in municipal solid waste amended soil. Agronomy Journal. 91:
1009- 1016.

Gallardo-Lara, F., and Nogales, R., 1987. Effect of the application of town refuse compost on the Soil-Plant System: A Review. Biological Wastes. 19: 35-62.

Giusquiani, P. L., Marucchini, C., and Businelli, M., 1988. Chemical properties of soils amended with compost of urban waste. Plant and Soil. 109:73-78.

Goyal, S., Dhull, S.K. and Kapoor, K.K., 2005. Chemical and biological changes during composting of different organic wastes and assessment of compost maturity. Bioresource Technology. 96: 1584-1591.

Grazia, J. D., Tittonell, P. A., Germinara, D., and Chiesa, A., 2003. Phosphorous and nitrogen fertilizer in sweet corn (Zea mays L.). Spanish Journal Agricultural Research. 1:103-107.

Hampton, M.O., Schafter, B., Bryan, H.H., and Hanlon, E.A., 1994, Nutrient concentrations, growth and yieldof tomato and squash in municipal solid waste amended soil. Horticultural Science. 29:785-788.

Iglesias-Jimanez, E., Garcia,V., Espino, M., and Hernandez, J., 1993. City refuse compost as a phosphorus source to overcome the $\mathrm{P}$ fixation capacity of sesqui oxide rich soils. Plant and Soil. 148: 115-127.

Iglesias-Jimenez, E., and Alvarez, C., 1993. Apparent availability of nitrogen in composted municipal refuse. Biology and Fertility of Soils.16: 313-318.

Jackson, M.L., 1973, Soil chemical analysis. Prentice Hall, New Delhi, pp. 1-485.

Lindsay, W.L., and Norwell, W.A., 1978. Development of DTPA soil test for zinc, iron, manganese and copper. Soil Science Society America Journal. 42: 421-428.

Logan, T. J., Lindsay, B.J., Goins, L.E. and Rayan, J.A., 1997. Field assessment of sludge metal availability to crops: Sludge rate response. Journal of Environmental Quality 31:1550-1560. 
Mamo, M., Rosen, C., and Halbach, T., 1999. Nitrogen availability and leachingfrom soil amended with municipal solid waste compost. Journal of Environmental Quality. 28: 1074-1082.

Mkhabela, M., and Warman, P.R., 2005. The influence of municipal solid waste compost on yield, soil phosphorus availability and uptake by two vegetable crops, grown in Pugwash sandy loam soil in Nova Scotia. Agriculture Ecosystems Environment. 106: 57-67.

Nogales, R., Gomez, M. and Gallardo Lara, F., 1985. Town refuse compost as a potential source of zinc for plants. In: Proceedings of International Conference of Heavy Metals in the Environment, 1: 487-489.

Prasad, P., and Sinha, N.P., 1981. Balance sheet of soil phosphorus and potassium as influenced by intensive cropping and fertilizer use. Plant and Soil. 60 (2): 187-193.

Roca-Pérez, L., Martínez, C., Marcilla, P., and Boluda, R., 2009. Compost rice straw with sewage sludge and compost effects on the soil-plant system. Chemosphere. 75: 781-787.

Sekar, S., Mohammed Amanullah, M., Manoharan, S. and Subramanian, K. S., 2009. Influence of fertilizer levels and growth substances on yield and quality of hybrid maize. Green Farming. 2: 889892.

Shanmugam, G.S., and Warman, P. R., 2004. Soil and plant response to organic amendments to three strawberry cultivars. In: Martin Neto, L., Milori,D., daSilva, W.,(Eds).
Proceedings of the International Humic substances Society. Embrapa (Pub.)Sao Petro, pp. 230-232.

Singh, D.P., Rana, N.S., and Singh, R.P., 2000. Growth and yield of winter maize (Zea mays L.) as influenced by intercrops and nitrogen application. Indian Journal of Agronomy. 45: 515-519.

Subbaiah, B.V., and Asija, G.L., 1956. A rapid procedure for the estimation of the available nitrogen in soil. Current Science. 25: 259-260.

Suryavanshi, V.P., Pagar, P.A., Dugmod, S.B. and Suryawanshi, S. B., 2009. Studies on leaf area pattern and dry matter accumulation in maize as influenced by spacing, nitrogen and phosphorous levels. International Journal Tropical Agriculture. 27: 223-226.

Warman, P. R., and Termeer, W.C., 2005. Evaluation of sewage sludge, septic waste and sludge compost applications to corn and forage: yields and N, P and $\mathrm{K}$ content of crops and soils. Bioresource Technology. 96: 955-961.

Warman, P.R., and Rodd, V., 1998. Influence of source-separated MSW compost on vegetable crop growth and soil properties: year 3. In: Proceedings ofthe 8th Annual Meeting of the Composting Council of Canada, Ottawa, Ontario, November 3-5, pp. 263-273.

Warman, P.R., 2001, Municipal solid waste compost effects tomato leaf tissue: essential plant nutrients and trace elements. In: Proceedings of the $6^{\text {th }}$ international Conference on the biogeochemistry of trace elements. Guelph, p.167.

\section{How to cite this article:}

1Karthika, K.S. Parama, V.R.R., Srinivasamurthy, C.A.,B.Hemalatha and Rashmi, I. 2018. Evaluation of Industrial Waste-Municipal Solid Waste Composts as a Source of Nutrients and a Study on its Effect on Soil Properties, Growth, Yield and Nutrient Uptake in Maize (Zea mays L.) Int.J.Curr.Microbiol.App.Sci. 7(07): 2249-2264. doi: https://doi.org/10.20546/ijcmas.2018.707.263 